Studia Kinanthropologica, XX, 2019, (1), 27-34

The Scientific Journal for Kinanthropology

KOMPARÁCIA HERNEHO A TECHNICKÉHO PRÍSTUPU K VÝUČBE BASKETBALU V EDUKAČNOM PROSTREDÍ TELESNEJ VÝCHOVY A ŠPORTU

\title{
COMPARISON OF GAMING AND TECHNICAL APPROACH TO BAS- KETBALL TEACHING IN THE EDUCATIONAL ENVIRONMENT OF PHYSICAL EDUCATION AND SPORT
}

\author{
A. Izáková, ${ }^{1}$ G. Argaj, ${ }^{2} \&$ K. Hůlka ${ }^{3}$ \\ ${ }^{1}$ Univerzita Mateja Bela v Banskej Bystrici, Filozofická fakulta, Katedra telesnej výchovy a športu \\ ${ }^{2}$ Univerzita Komenského v Bratislave, Fakulta telesnej výchovy a športu, Katedra športových hier \\ ${ }^{3}$ Univerzita Palackého v Olomouci, Fakulta tělesné kultury, Katedra sportu
}

\begin{abstract}
The contribution presents a view of the didactic aspect of teaching sports games, in our case the teaching of sports game basketball. The authors pay attention to the didactic approach, which is nowadays in the development of didactics and practice. The aim of our contribution was to compare two selected approaches to basketball teaching in physical education and sports. It is gaming and technical approach. To each of approaches we have presented examples of how to practice basketball teaching by using selected methodological and organizational forms.
\end{abstract}

Keywords: basketball; physical education and sport; didactical approach to teaching

\section{Súhrn}

Príspevok prezentuje pohlad na didaktickú stránku vyučovania športových hier, v našom prípade na vyučovanie športovej hry basketbal. Autori venujú v príspevku pozornost̉ didaktickým prístupom, ktoré sa dnes presadzujú v doterajšom vývoji didaktiky a praxe. Cielom nášho príspevku bolo porovnat’ dva vybrané prístupyk výučbe basketbalu v edukačnom prostredí telesnej výchovy a športu. Ide o herný a technický prístup. $\mathrm{K}$ jednotlivým prístupom sme uviedli príklady postupu realizácie vyučovania basketbalu s využitím vybraných metodicko-organizačných foriem.

Klúčové slová: basketbal; telesná a športová výchova; didaktický prístup vyučovania

\section{Úvod}

Športové hry patria už dlhodobo medzi najoblúbenejšie tematické celky v školskej telesnej a športovej výchove. Táto všeobecne známa oblúbenost športových hier v školskom prostredí je potvrdzovaná domácimi aj zahraničnými výskumami (Psotta \& Velenský, 2001). Jednou z týchto športových hier je aj basketbal, ktorý napriek vysokej technickej náročnosti herných zručností, patrí spolu s futbalom celosvetovo medzi najpopulárnejšie športové hry a stále viac a viac preniká aj do popoludňajších záujmových telovýchovných foriem na všetkých typoch a stupňoch škôl (Velenský, 1999).

Už v samotnej histórii tejto športovej hry, ktorej vznik sa datuje od decembra 1891 v Springfielde, sa potvrdzuje, že basketbal patril medzi také pohybové aktivity, ktoré mali poskytovat na školách predovšetkým rozptýlenieštudentov rámci ich volnočasových aktivít (Horička, 2014). Napriek tomu bola táto hra od svojich počiatkov, pri množstve meniacich sa pravidiel, technicky velmi náročná, kedže ide o zložitý komplex pohybov jednotlivých častí tela, vykonávaných súčasne alebo následne (Dobrý, 1986). Basketbal vyžaduje vysokú úroveň riadenia týchto pohybov, svalovú koordináciu, jemnú diferenciáciu, ale vyžaduje aj vysokú úroveň pohybových schopností a špeciálnych zručností (Horička, 2014). Dosiahnutie takejto požadovanej úrovne je aj jednou z úloh výučby športovej hry basketbal v edukačnom prostredí školskej telesnej a športovej výchovy. Je len na učitelovi telesnej a športovej 
výchovy, aké didaktické metódy a postupy si zvolí na jej dosiahnutie, príp. aký didaktický prístup vyučovania športových hier zvolí, aby čo najviac motivoval žiakov k učeniu a dosiahnutiu čo najlepšieho výkonu.

V rámci didaktiky športových hier sa stretávame hned’s niekolkými didaktickými prístupmi. Nemec et al. (2013), Psotta \& Velenský, (2001) rozdelujú prístupy vyučovania na základe obsahu a štruktúry učiva, spôsobov usporiadania učebných podmienok a didaktickej interakcie učitela. Ide o:

- neštruktúrovaný prístup,

- integrovaný prístup,

- technický prístup.

K nim sa pridáva ešte herný prístup vyučovania športových hier, ktorý preferujú napr. Martens (2006), Neumann \& Popovic (2010).

Neštruktúrovaný prístup, v zahraničí označovaný aj ako „laissez-fair” alebo "ball-rollerapproach", je prístup, kedy sa vyučovanie športových hier nečlení do menších celkov a obsahom každej vyučovacej hodiny je zápas bez herného nácviku. Hoci existujú názory, že tento prístup podnecuje samostatnost žiakov, musíme pripustit fakt, že tento prístup nie je z hladiska učenia dostatočne efektívny, pretože poznatky z edukačného prostredia jasne ukazujú, že neustále opakovanie komplexného neštruktúrovaného celku nestačí na efektívne zdokonalovanie pohybových schopností a zručností žiaka. Ide totiž o učenie na základe pokusu a omylu, ktorý vyžaduje príliš vela času v praxi. Preto sa odporúča jeho využitie skôr vo vyššom školskom veku (Nemec et al., 2013, Psotta \& Velenský, 2001).

Integrovaný prístup, ktorého súčasti sú:

- Prístup založený na postupnej integrácii kognitívnych a pohybových komponentov herného výkonu;

- Taktický prístup založený na porozumení športovej hry;

- Prístup založený na alosterickom modely učenia.

Integrovaný prístup, v zahraničí známi pod skratkou TGFU, „Teaching Games for Understanding”, je prístup vyučovania športových hier, ktorý je založený na rýchlejšom rozvíjaní herných činností a herných situácií, na postupnom prechode od učenia herných zručností v menej premenlivých podmienkach $\mathrm{k}$ praxi s variabilnejšími podmienkami. Zahrňuje tiežtaktické stránkyindividuálnych herných činností pri riešení herných úloh obsiahnutých $\mathrm{v}$ herných situáciách. Výhodou tohto modelu je, že zvyšuje zapájanie žiakov do fyzickej aktivity a povzbudzuje ich, aby mysleli viac takticky a robili lepšie rozhodnutia v hre (Nemec et al., 2013, Psotta \& Velenský, 2001). Potvrdzujú to aj výskumy French \& Thomas (1987), ktorí zistili, že sa ich subjekty vplyvom tohto prístupu zlepšili v kognitívnych rozhodovacích a kontrolných prvkoch výkonnosti a znalosti z basketbalu v priebehu výskumného obdobia.

Technický prístup, často označovaný ako „tradičný” prístup k vyučovaniu športových hier, sa využiva najčastejšie v školskej telesnej a športovej výchove. V podstate je opozitom k predchádzajúcim prístupom, pretože jeho hlavným zámerom je zdokonalovanie herných zručností mimo situácíi vyskytujúcich sa v reálnej hre žiaka (Nemec et al., 2013, Griffin, Mitchel \& Oslin, 1997). Častým problémom $\mathrm{v}$ technickom prístupe vyučovania športových hier je, že sa žiaci nudia, pretože ide o drilové monotónne opakovanie cvičení, vyžadujúce si vela času a žiaci trávia tento čas skôr čakaním, až na nich príde rada, miesto toho, aby dostávali priestor riešit problémy tak rýchlo, ako je to v skutočnej hre, ktorá si naopak vyžaduje dobré taktické schopnosti, správne rýchle rozhodnutia, prostredníctvom ktorých sa zvyšujú šance na výhru (Martens, 2006). Vo vyučovaní športových hier tu prevláda vyučovací postup po častiach, z dôrazom na techniku, ktorá sa vyučuje individuálne (Hopper, 2001, Radu, 2010), príp. vo dvojiciach, čo má za následok síce „zručných” hráčov, ale v praxi, v samotnej hre „nepoužitelných”, bez schopnosti samostatného rozhodovania sa. Väčšina orientácie vyučovacieho procesu je na učitela, nie na žiaka (Nemec et al., 2013, Psotta \& Velenský, 2001).

Herný prístup môžeme považovat za určitý typ holistického prístupu učenia sa športovým zručnostiam, ktorý je zameraný najprv na pomoc športovcom pochopit hru komplexne a objavit ich úlohu $\mathrm{v}$ tejto hre (Martens, 2006). Je jedným z prístupov, ktorého využitie pri výučbe športovej hry basketbal zodpovedá súčasnému edukačnému prostrediu a jeho požiadavkám. Priekopníkom herného prístupu bol Launder (2001). Jeho základom je výučba basketbalu, ktorá sa začína hrou (vlastnou hrou, prí- 
pravnou hrou) a potom sa pokračuje učením jednotlivých herných činností. Ďalej sa v ňom vychádza z princípov integrovanej hernej praxe (integrated game practice) a z analýzy didaktickej reality pri vyučovacom procese. Jeho podstatou je spojenie učenia herných zručností s taktickou stránkou konania hráča a s taktickým uvedomením si podstaty hry. Herný prístup charakterizujú tieto znaky (Martens, 2006):

- Používajú sa len tie drilové cvičenia, ktoré sú spojené s vlastnou hrou.

- Učí sa prostredníctvom reálnej hry a potom sa zdokonalujú jej jednotlivé časti.

- Hráč je centrom všetkých činností.

- Tréningy sú zábavné, relevantné a sú pre športovca výzvou, ktorá zvyšuje vnútornú motiváciu.

- Tréningy sú zamerané na rozvoj myslenia, porozumenia (hre) a rozvoj rozhodovacích schopností.

Niektorí autori používajú inú terminológiu v súvislosti s herným prístupom, napr. Steinhöfer \& Remmert (1998) používajú termín priama vyučovacia metóda a v nej postupujú od prípravnej hry k minibasketbalu a nakoniec k basketbalu. Olosová, (2012), Psotta \& Velenský, (2001) hovoria o výučbe športových hier s porozumením, príp. o taktickom prístupe, kde učenie taktických zručností umožňuje realizovat technické zručnosti v zápasových podmienkach. Význam tohto učenia zvýrazňuje Edukačný program ASEP, (2007), na ktorý nadväzuje napr. aj Schowalter (2009). Ten odporúča napr. zarad’ovat? do praxe čo najviac prípravných hier a vytvárat ich rôzne varianty.

Na základe získaných teoretických poznatkov, v otázke prístupu k vyučovaniu športovej hry basketbal, uvádzame podstatné rozdiely, výhody, pozitíva herného prístupu, v porovnaní s dnes ešte stále častejšie v praxi využívaným tradičným, technickým prístupom.

Tabulka 1./ Table 1.

Komparácia herného a technického prístupu $k$ výučbe basketbalu./ Comparison of gaming and technical approach to basketball teaching.

\begin{tabular}{|c|c|}
\hline Technický prístup & Herný prístup \\
\hline $\begin{array}{c}\text { Používa drilové cvičenia bez spojenia s hernou } \\
\text { situáciou. }\end{array}$ & $\begin{array}{c}\text { Použiva len tie drilové cvičenia spojené s hernou } \\
\text { situáciou. }\end{array}$ \\
\hline $\begin{array}{c}\text { Učenie od častí k celku, analyticko-syntetický } \\
\text { vyučovací postup. }\end{array}$ & $\begin{array}{c}\text { Učenie od celku k častiam synteticko-analytický } \\
\text { vyučovací postup. }\end{array}$ \\
\hline Orientácie vyučovacieho procesu je na učitela. & Orientácie vyučovacieho procesu je na žiaka. \\
\hline $\begin{array}{l}\text { Nudné a demotivujúce hodiny telesnej a } \\
\text { športovej výchovy. }\end{array}$ & $\begin{array}{l}\text { Zábavné hodiny telesnej a športovej výchovy, } \\
\text { zvyšujúce motiváciu žiaka. }\end{array}$ \\
\hline $\begin{array}{c}\text { Rozvoj automatických reakcií bez herného } \\
\text { myslenia. }\end{array}$ & $\begin{array}{l}\text { Rozvoj myslenia, porozumenia a schopnosti } \\
\text { rozhodovat sa. }\end{array}$ \\
\hline Absentuje spolupráca učitel’ - žiak. & $\begin{array}{c}\text { Žiaci spolupracujú s učitelom a pomáhajú mu } \\
\text { pri rozhodovaní. }\end{array}$ \\
\hline $\begin{array}{c}\text { Žiaci nie sú vedení k vzájomnej pomoci pri } \\
\text { zlepšovaní herných zručností. }\end{array}$ & $\begin{array}{c}\text { Žiaci sú vedení k vzájomnej pomoci pri } \\
\text { zlepšovaní herných zručností. }\end{array}$ \\
\hline Preferovanie autoritatívneho vyučovacieho štýlu. & Preferovanie kooperatívneho vyučovacieho štýlu. \\
\hline
\end{tabular}

Zdroj: vlastný (podla Martens, 2006).

V súvislosti s riešením projektu KEGA č. 026UMB-4/2017, ktorý je zameraný na tvorbu učebných textov a učebných pomôcok zaoberajúcich sa teóriou adidaktikou basketbalu, uvedieme v d’alšej časti príspevku ukážku postupu výučby športovej hry basketbal technickým prístupom a pre porovnanie herným prístupom. Skôr ako sme si zvolili postup výučby, formulovali sme si základné východiská pre vyučovanie športovej hry basketbal s vybranými didaktickými prístupmi.

V technickom prístupe sme pri usporiadaní učiva použili: 
- Analyticko-syntetický vyučovací postup (od častí k celku), čo znamenalo pri výbere metodickoorganizačných foriem, že výučba basketbalu začínala drilovými, prípravnými cvičeniami zameranými na nácvik herných činností, s dôrazom na technickú stránku ich prevedenia a až ovela neskôr sa začala uplatňovat prípravná a vlastná hra.

- Osvojovanie technických zručností bolo nadradené rozvoju taktického myslenia.

- Na vyučovaní sa preferoval príkazový a praktický riadiaci štýl.

Obrázok 1./ Figure 1.

Metodicko-organizačné formy./ Methodical-organizational forms.

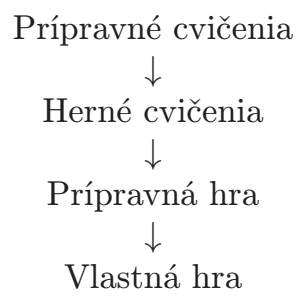

Príklad postupu pri výučbe technickým prístupom.

Obrázok 2./ Figure 2.

Strelba - prípravné cvičenie./Shooting - preparatory practice.

1. krok./Step 1.

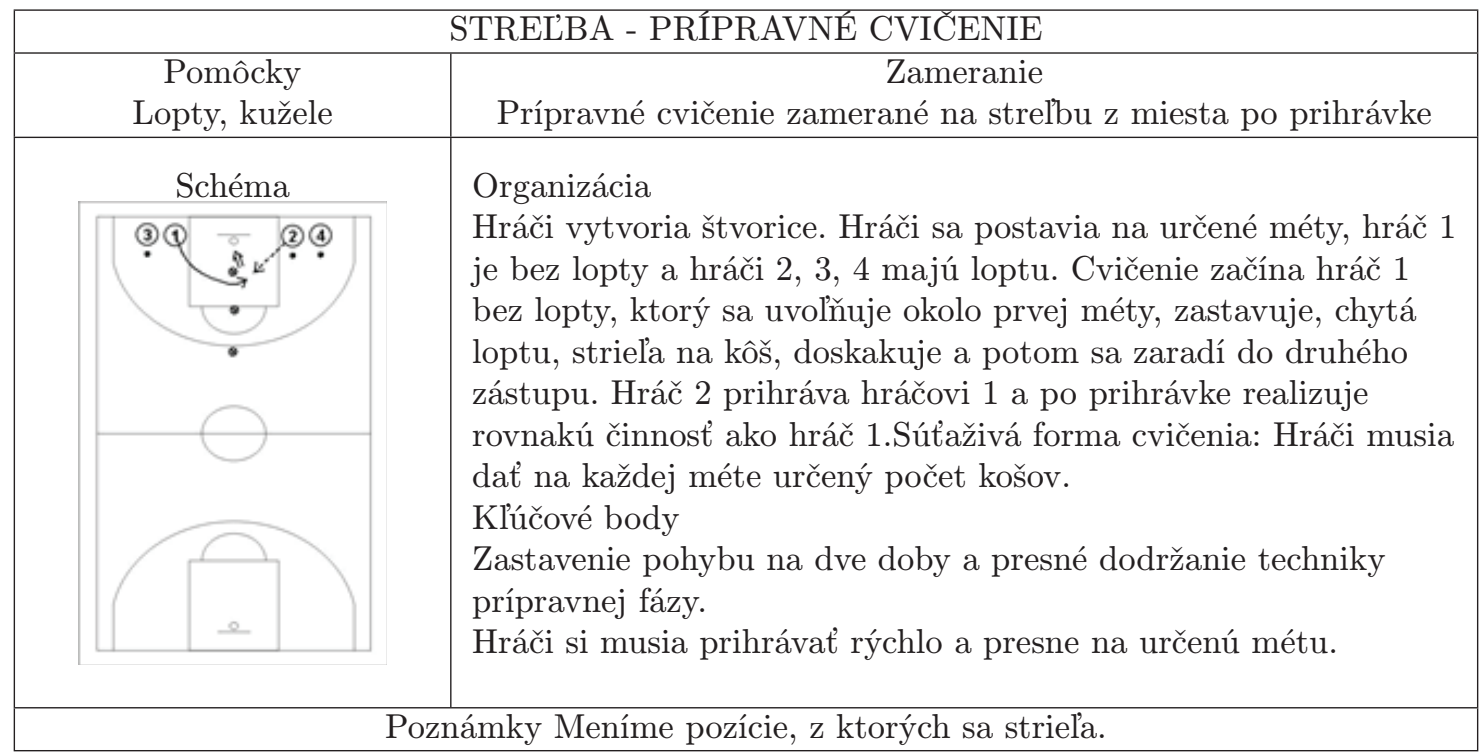


Obrázok 3./ Figure 3.

Strelba - herné cvičenie./ Shooting-game practice.

2. krok/. Step 2.

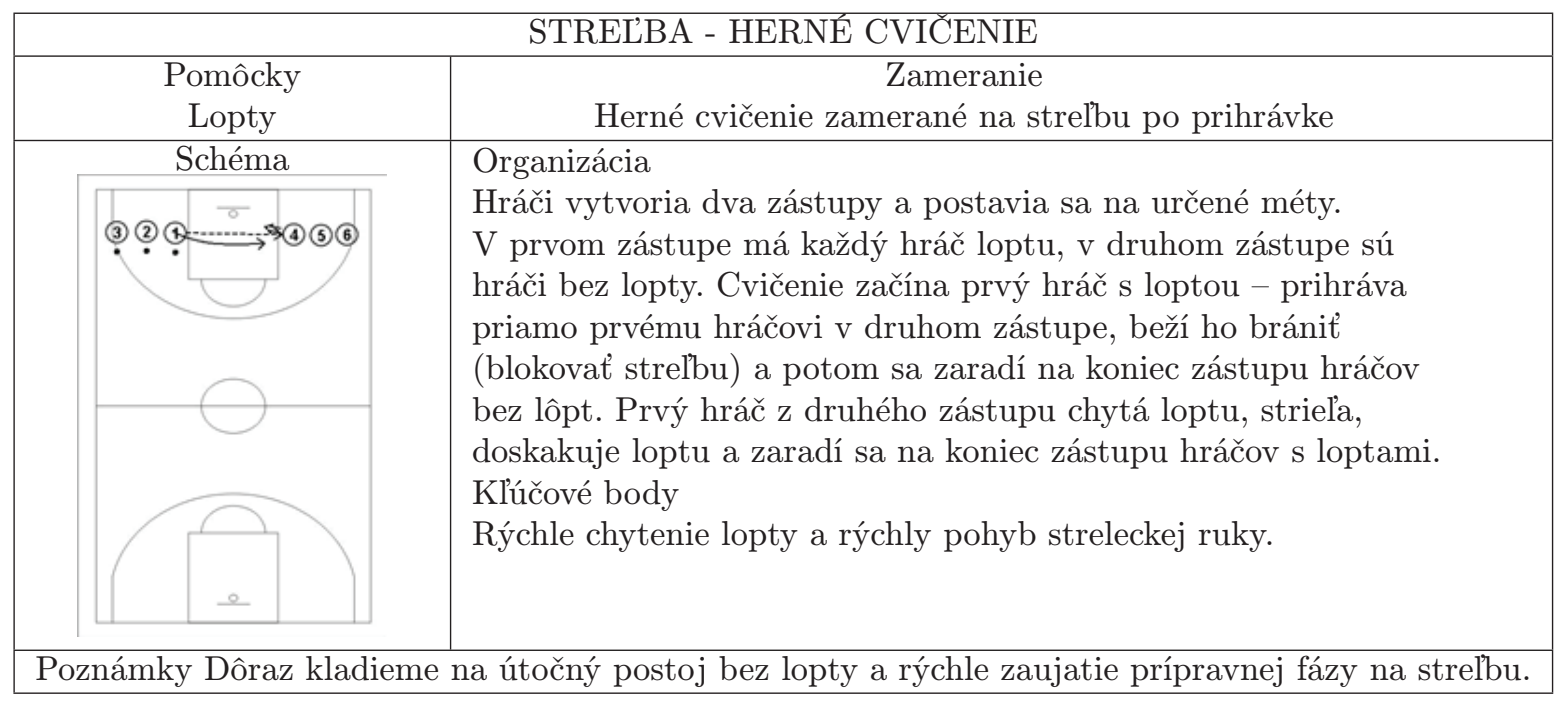

Obrázok 4./ Figure 4.

Strelba - prípravná hra./ Shooting - auxiliary play.

3. krok./Step 3.

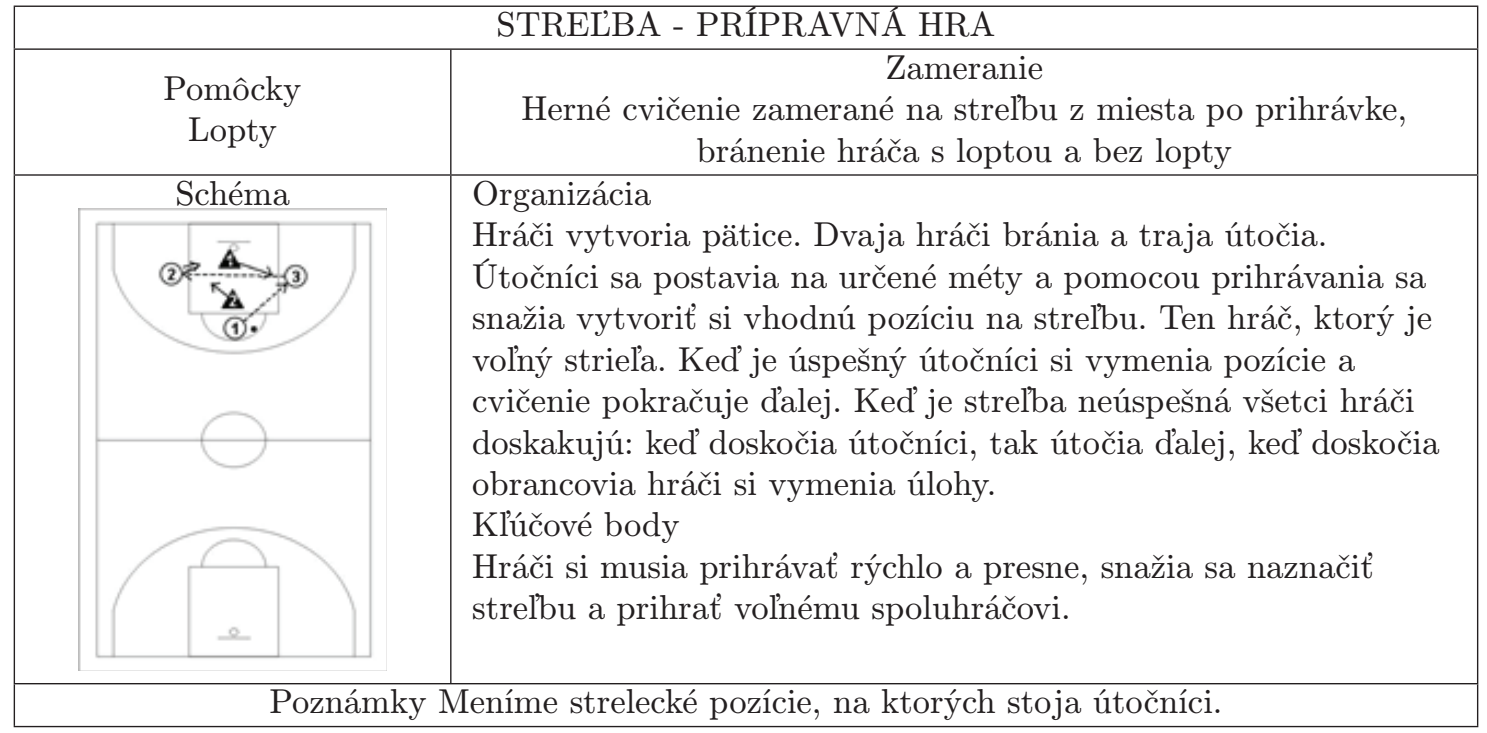

V hernom prístupe sme pri usporiadaní učiva použili:

- Synteticko- analytický vyučovací postup (od celku k častiam), čo znamenalo pri výbere metodickoorganizačných foriem, že výučba basketbalu začínala prípravnou hrou, na ktorú nadväzujú zložky integrovanej praxe (Dobrý, 2013).

- Rozvoj taktického myslenia bol nadradený nad osvojovaním technických zručností.

- Na vyučovaní sa preferoval didaktický štýl s riadeným a samostatným objavovaním. 
Obrázok 5./ Figure 5.

Integrovaná herná prax./ Integrated game practice.

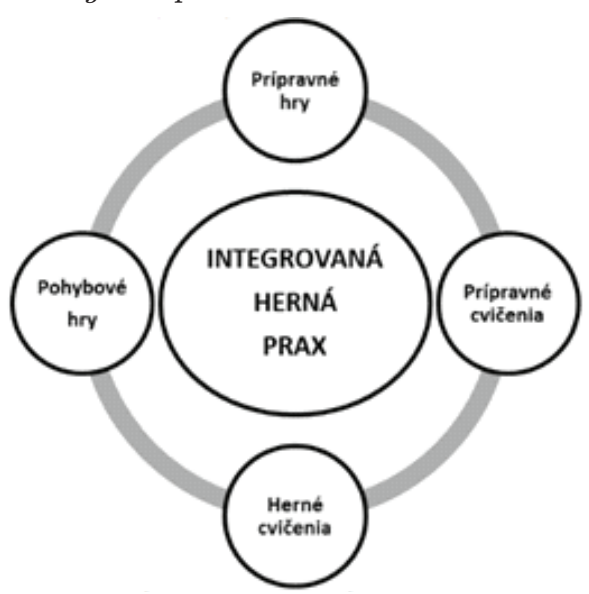

Príklad postupu pri výučbe herným prístupom.

Obrázok 6./ Figure 6.

Strelba - prípravná hra./ Shooting - auxiliary play.

1. krok./Step 1.

\begin{tabular}{|l|l|}
\hline \multicolumn{2}{|c|}{ PRIHRÁVANIE A CHYTANIE LOPTY - PRİPRAVNÁ HRA } \\
\hline $\begin{array}{l}\text { Pomôcky } \\
\text { Lopty }\end{array}$ & $\begin{array}{l}\text { Zameranie } \\
\text { Prípravná hra zameraná na prihrávanie a chytanie lopty, } \\
\text { bránenie hráča s loptou a bez lopty, prípravná hra 2:2 }\end{array}$ \\
\hline Organizácia \\
Hráčov rozdelíme do dvoch družstiev a vytvoríme dvojice \\
hráčov. V každom území sa hrá 2:2 bez driblingu. \\
Uzemia: \\
dvojbodová zóna I, trojbodová zóna I, trojbodová zóna II, \\
dvojbodová zóna II. \\
Klúčové body \\
Nadviaž kontakt s obrancom a prudko zmeň rýchlost a smer \\
pohybu.
\end{tabular}

Druhý krok výberu metodicko-organizačných foriem vo vyučovaní basketbalu s využitím herného prístupu záleží od zvládnutia prvého kroku. V prípade, že žiak robí v prípravnej hre vel’a chýb v nepresnosti prihrávok aj bez tlaku obrancu, nasledujúcim krokom budú prípravné cvičenia. 
Obrázok 7./ Figure 7.

Prihrávanie a chytanie lopty-prípravné cvičenia./ Passing and catching the ball-preparatory practice. 2A. krok./Step $2 A$.

\begin{tabular}{|c|l|}
\hline \multicolumn{2}{|c|}{ PRIHRÁVANIE A CHYTANIE LOPTY - PRÍPRAVNÉ CVIČENIE } \\
\hline $\begin{array}{l}\text { Pomôcky } \\
\text { Lopty }\end{array}$ & $\begin{array}{c}\text { Zameranie } \\
\text { Prihrávanie a chytanie lopty, prípravné cvičenie s premenlivými } \\
\text { podmienkami }\end{array}$ \\
\hline Schéma & $\begin{array}{l}\text { Organizácia } \\
\text { Hráči sa postavia do zástupu, prvý hráč má loptu. Na signál sa } \\
\text { hráči lubovolne pohybujú na ihrisku a prihrávajú si v určenom } \\
\text { poradí - prvý druhému, druhý tretiemu, posledný prvému atd. } \\
\text { Klúčové body } \\
\text { Najskôr hráč chytí loptu, zastaví (skokom na dve nohy) a potom } \\
\text { prihrá. Hráč, ktorý má dostat prihrávku sa uvolňuje tak, aby bol } \\
\text { vo výhodnej pozícii. Neskôr si hráči prihrávajú bez zastavenia. }\end{array}$ \\
\hline
\end{tabular}

V prípade, že žiak robí v prípravnej hre vela chýb v nepresnosti prihrávok len pod tlakom obrancu, nasledujúcim krokom budú herné cvičenia.

Obrázok 8./ Figure 8.

Prihrávanie a chytanie lopty - herné cvičenie./ Passing and catching the ball - game practice. $2 B$. krok/Step $2 B$.

2B. krok./Step $2 B$.

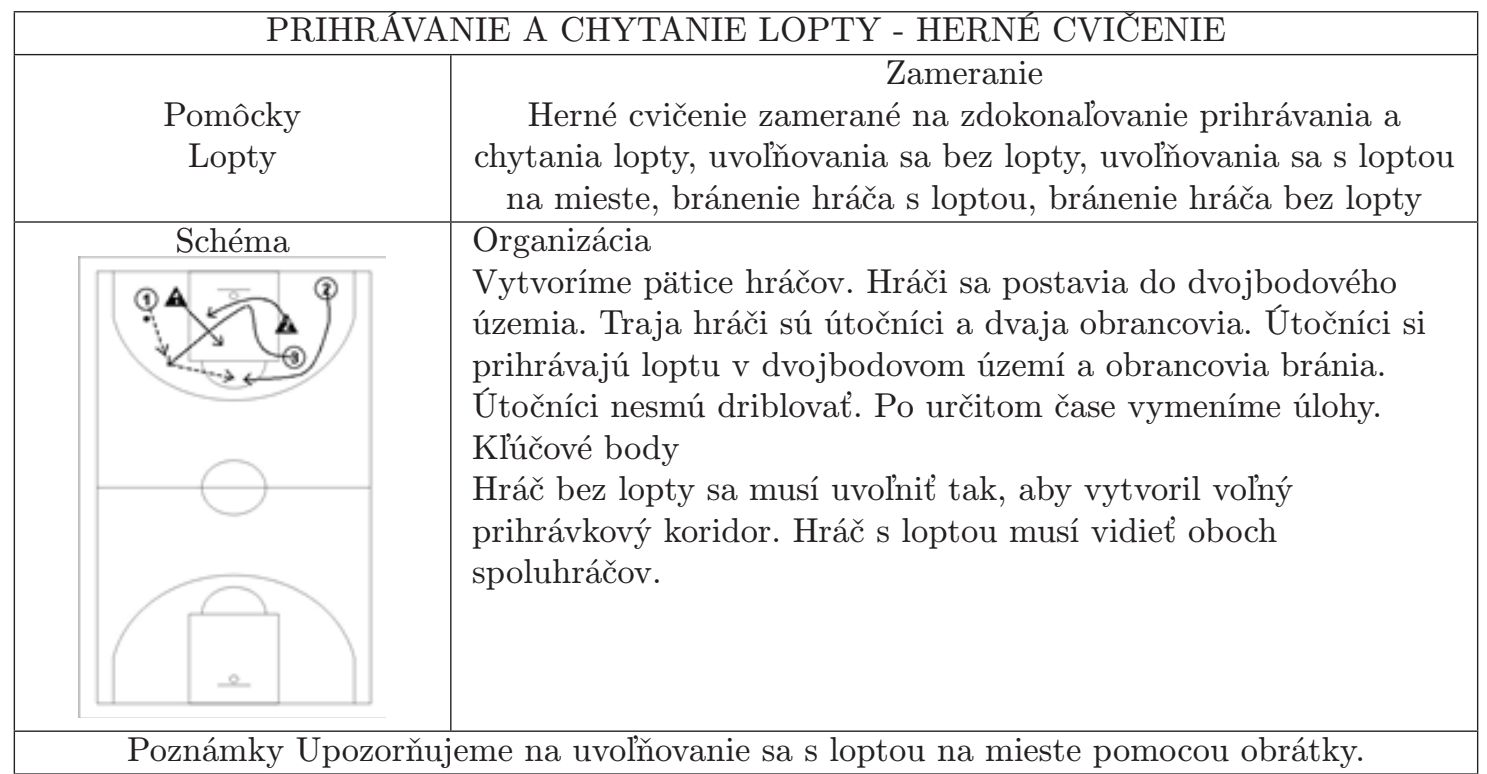




\section{Záver}

Postupné presadzovanie herného prístupu vyučovania športových hier v edukačnom prostredí, a teda aj športovej hry basketbal, je daný práve tým, že úspech v športe nie je daný len technickými a taktickými zručnostami, ale celkovým rozvojom hráčov (žiakov), do ktorého spadá aj úroveň obratnosti, mentálnych schopností a komunikačných zručností. Je len na učitelovi telesnej a športovej výchovy, aký prístup k vyučovaniu si zvolí, ked' zváži všetky podmienky danej školy.Ak učitel pochopí výhody a obsah vyučovania herného prístupu, odmenou mu budú žiaci, ktorí sa budú učit a hrat? basketbal lepšie, ale budú sa z hry aj omnoho viac radovat'. Hra totiž vytvára predpoklady pre tvorivé myslenie, tvorivé riešenie herných situácií, čo by mali učitelia podporovat a malo by byt ich prioritou pre zefektívnenie a zatraktívnenie vyučovania športových hier.

\section{Literatúra}

ASEP. (2007). Coaching Basketball Technical and Tactical Skills.Champaign: Human Kinetics.

Dobrý, L. (1986). Malá škola basketbalu. Praha: Olympia.

Dobrý, L. (2013). Cesta do tajů herního přistupu v basketbalu. In Tělesná výchova a sport mládeže. Praha: Fakulta tělesné výchovy a sportu Univerzity Karlovy v Praze, 79(4), 47-48.

French, E. K., \& Thomas, J. R. (1987). The Relationoff Knowledge Development to Children's Basketball Performance. Získané 28.9.2018, z https://journals.humankinetics.com/doi/10.1123/jsp.9.1.15.

Griffin, L., Mitchel, S., \& Oslin, J. (1997). Teaching sports concepts and skills. A tactical game approach. Champaign: Human Kinetics.

Hopper, T. (2001). What is a TGFU approach to games teaching and what's wrong with teaching skills? Tactic-to-skill games teaching. Získané 28.9.2018, z http://web.uvic.ca/ thopper/WEB/articles/ Joperd/Skillswrong.htm.

Horička, P. (2014). Basketbal. Teória a didaktika. Nitra: PF UKF v Nitre.

Launder, A. (2001). Play practise: The Games Approach to teaching and coaching sport. Champaign: Human Kinetics.

Martens, R. (2006). Úspěšný trenér. Praha: Grada Publishing.

Nemec, M., Adamčák, Š., Kučera, M., Kollár, R., Izáková, A., \& Popelka, J. (2013). Športové hry 1. Cast. Banská Bystrica: Belianum.

Neumann, H., \& Popovic, S. (2010). Spielend Basketball lernen. Wiebelsheim: Limpert Verlag.

Olosová, G. (2012). Účinnost’ taktického a technického prístupu k výučbe minibasketbalu na rozvoj herného výkonu a pohybových schopnosti (Diplomová práca, Univerzita Komenského, Bratislava, Slovensko).

Schowalter, D. (2009). Coaching Youth Basketball. Champaign: Human Kinetics.

Psotta, R., \& Velenský, M. (2001). Aternativní pojetí vyučování sportovních her ve školní tělesné výchově. In Pedagogická kinantropologie. Praha: Karolinum.

Radu, A. (2010). Basketball. A guide to skills, techniques and tactics. Ramsbury, Marlborough: The Crowood Press.

Velenský, M. (1999). Basketbal. Praha: Grada Publishing, spol. s. r. o.

Mgr. Andrea Izáková, PhD.

Katedra telesnej výchovy a športu

Filozofická fakulta

Univerzita Mateja Bela

Tajovského 40

97401 Banská Bystrica

Slovenská republika 